\title{
INNOVATIVE DEVELOPMENT OF UKRAINE IN THE CONTEXT OF IMPLEMENTATION OF THE ASSOCIATION WITH EU
}

\author{
Igor Matyushenko \\ Doctor of Economic Sciences, Professor \\ V.N. Karazin Kharkiv National University \\ Svobody sq., 4, Kharkiv, Ukraine, 61022 \\ e-mail: imatyushenko@karazin.ua, ORCID: https://orcid.org/0000000198669025 \\ Nataliia Redko \\ Student \\ V.N. Karazin Kharkiv National University \\ Svobody sq., 4, Kharkiv, Ukraine, 61022 \\ e-mail: natalia.redko98@gmail.com, ORCID: https://orcid.org/0000-0002-1085-5673
}

\begin{abstract}
The signing of the Association Agreement in 2014 provides for the development of innovation cooperation between Ukraine and the EU, so it is appropriate to analyze the development of innovation in Ukraine since the signing to assess the effectiveness of the agreement and identify weaknesses and strengths of Ukraine as an innovator and make appropriate recommendations. The object of the research of the article is the innovative development of country and accordingly the subject is the current state of the innovative development of Ukraine in the conditions of implementation of the Association agreement with Europen Union. The goal of the research is to determine the level of innovation development in Ukraine, highlight the main advantages and disadvantages and provide appropriate recommendations for improving the conditions of innovation development in the country in the framework of the Association Agreement.

To achieve the goal of the the research analysis of the dynamics of indicators that characterize the level of innovation development in the country since the signing of the Agreement was conducted. The database is international rankings such as the Global Innovation Index, the Bloomberg Innovation Index, the Global Competitiveness Index and the EU Innovation Scoreboard.

Results: based on the analysis of the dynamics of indicators of the level of innovation development in Ukraine, weaknesses that prevent Ukraine from realizing its innovation potential are identified and a correlation coefficient to assess the relationship between GDP per capita and the level of innovation development is calculated. Conclusions: despite the current Agreement between Ukraine and the EU, which should stimulate the development of technology in Ukraine, the level of innovative development in the country still remains low and lags far behind the level of EU states. Thus, Ukraine does not take full advantage of the Association Agreement. The given recommendations for increasing the level of innovation development in Ukraine based on european experience should help develop a strategy for the creation and implementation of innovations, find ways to increase the competitiveness of the Ukraine's economy by implementation its innovation potential.
\end{abstract}

Keywords: : Association Agreement with EU, european integration, indicators of the level of innovation development, innovation potential.

Formulation of the problem. Sustainable development of Ukraine's economy is impossible without the intensification of innovation within the country. The developed innovation system of the country allows it to combine economic and social relations, knowledge and technological innovations. Effective innovation potential is not only a way of dynamic development, but also a means of ensuring the security and sovereignty of the country and its competitiveness in the modern world. In 2014 Ukraine signed the Association Agreement with the EU, which provides for the creation of a free trade area and is the first step to deepen Ukraine's European integration. The text of the agreement also refers to cooperation in the field of innovation. Section V states that cooperation between Ukraine and the EU in the field of technology and science provides mutual exchange of information on programs that enable the implementation of joint projects at the level of governments, research institutions, enterprises, as well as the participation of Ukrainian organizations in various areas of the EU Framework Program for Research and Innovation "Horizon" [3]. Therefore, the analysis of the level of innovative development of Ukraine will allow to develop a strategy for the implementation of innovations, find ways to increase the competitiveness of the economy by realization of its innovation potential. This is currently very important for Ukraine, as Ukraine is most interested in the development of innovative cooperation with the EU, as it provides an opportunity for economic development, which is one of the main factors for Ukraine's European integration choice.

Analysis of research and publications. Many domestic economists have considered the problem of assessing the readiness of countries for innovative change. Thus, M. Kyzym in his works [13] considers the problems of assessing Ukraine's readiness for innovation transformations and assessed the possibility of forming innovation clusters; I. Egorov, I. Odotyuk and O.Salikhova [9] consider the possibility of implementing high technologies in the economy of Ukraine and evaluated the indicators of ICT development, biotechnology, nanotechnology, new materials and nuclear technologies. Alla Rusnak and Svitlana Prokhorchuk study the innovative capacity of Ukraine's economy in the international context [2]. Ye.I. Maslennikov and M.I. Dimitrieva in their work analize innovative development of the industry [19]. A. Kniazevych, V. Kyrylenko and L. Golovkova in their worl study how to improve innovation infrastructure of Ukraine [1]. 
Many foreign economists have studied the innovative development of the state, in particular: K. Schwab, W. Bainbridge, E. Brinolfsson, J. Ito, S. Greengard, K. Kelly, D. Ross, D. Rose, J. Howe, etc.

The object of research of the article is the innovative development of Ukraine, and accordingly the subject is the current state of development of innovations in the country.

The purpose of the research is to determine the level of innovation development in Ukraine, highlight the main advantages and disadvantages and provide appropriate recommendations for improving the conditions of innovation development in the country in the framework of the Association Agreement.

Results. Determining the level and state of development of innovations in Ukraine in the international context, in particular in the framework of European integration processes will be performed in accordance with international ratings that assess innovation potential, technological and innovative competitiveness. To do this, we studied and analyzed the most authoritative ratings in determining the innovation potential of the economy, namely: the Global Innovation Index, the Bloomberg Innovation Index, the Global Competitiveness Index and the EU Innovation Scoreboard.

The Global Innovation Index is being prepared jointly by Cornell University, INSEAD Business School and the World Intellectual Property Organization. In 2019, the Global Innovation Index covered 129 world economies based on 82 indicators, which are divided into seven areas: institutions, human capital and research, infrastructure, market sophistication, business sophistication, knowledge and technology outputs and creative outputs. Therefore, consider the dynamics of these sub-indices for Ukraine since the signing of the association agreement, ie since 2014.

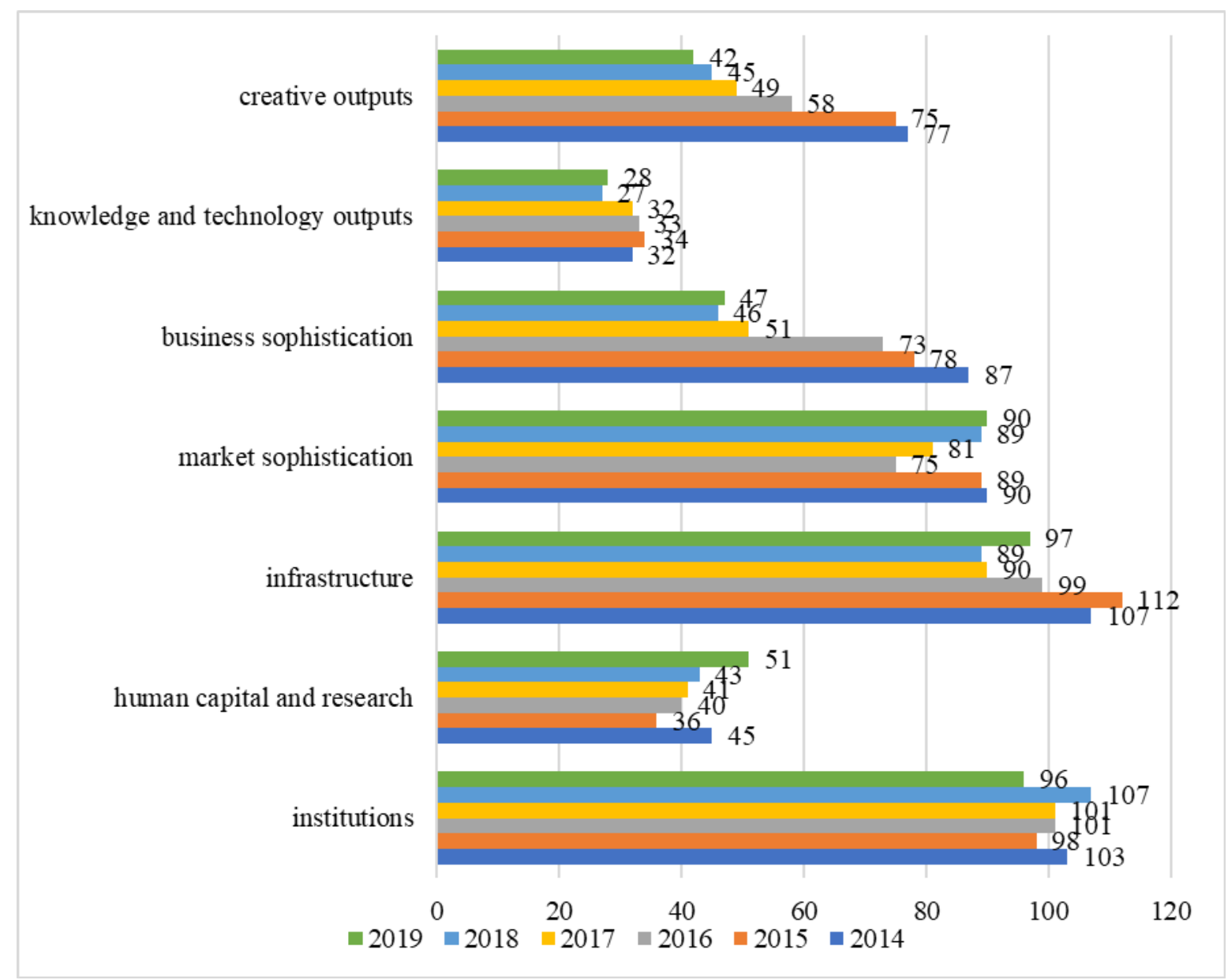

Fig. 1. Dynamics of sub-indices of the Global Innovation Index for Ukraine 2014-2019

Developed by the authors based on [16]

If we look at the dynamics as a whole, we can see that since the signing of the Association Agreement, Ukraine has improved its performance in almost all sub-indices of the Global Innovation Index rating. So, the greatest achievements can be seen in the development of the sub-index of creative potential. While in 2014 Ukraine ranked only 77 th in this indicator, in 2019 the country ranks 42nd among 129 70 countries. Over the past five years, Ukraine has risen 35 positions, which is currently its best result.

According to the sub-index of knowledge and technology creation, Ukraine ranks 28th, ahead of EU countries such as Slovenia (40), Slovakia (29), Poland (39), Romania (41), Bulgaria (37), Portugal (43), and Latvia (45). So, in five years, Ukraine has improved its results by four steps, compared to 2014, when Ukraine 
ranked 32nd, however, the best result was in 2018 , when Ukraine took 27 th place. In addition, it can be seen that Ukraine has the highest position among all other sub-indices in terms of knowledge and technology creation, which shows that the country's scientific and educational potential, knowledge of the population are the greatest advantages of Ukraine that currently ensure the country's competitiveness in innovation.

Analyzing the business development indicator, we can say that Ukraine has also improved its results here. Thus, in 2019, Ukraine ranks 47 th against 87 th in 2014, ahead of Croatia (49), Romania (51) and Greece (59). The country rose by 40 positions over the past five years, but still lags far behind most EU countries.

Speaking about the degree of market development in Ukraine, it is worth noting that Ukraine remained at the level of 2014 and ranks 90th among all studied economies. This is the lowest figure compared to all EU countries. Ukraine had the best result in 2016, when it took the 75 th place.

In terms of infrastructure development, Ukraine has the worst result among all seven indicators - 97th place. Although the country improved its results compared to 2014 (107th place), it lost 8 positions compared to 2018, when it took 89th place, which is currently the best result of Ukraine in terms of infrastructure development. Therefore, it can be said that the state of development of the infrastructure necessary for the development of innovations remains at an openly low level. Ukraine also lags far behind all EU countries. Thus, the worst result in terms of infrastructure development among all EU countries belongs to Latvia, which ranks 51st. Thus, Ukraine lags behind the worst indicator of the EU by 46 positions.

According to the sub-index of human capital and research, Ukraine ranked 51st in 2019, which is the best indicator of the country after knowledge and technology outputs and creative outputs. However, compared to 2014, the country lost six positions (51st place against 45 th). The best result was 36th place in 2015. Then the country began to gradually lose its position: 40th, 41st, 43rd and 51st places, respectively. Although Ukraine is ahead of Bulgaria (62nd) and Romania (69th) and still lags behind the European Union. Thus, human capital is the driving force of innovation, but needs considerable attention from the public and private sectors, as the country may lose one of its strongest competitive advantages.

In terms of the quality of institutions, Ukraine ranks 96th, which is the second worst result of Ukraine after the indicator of infrastructure development. Compared to 2014, Ukraine has risen seven places (106th place in 2014), which is its best result in five years. However, compared to the EU in 2019, Ukraine lags behind the worst result, which belongs to Greece by 45 positions (Greece in 2019 took 51st place). Thus, the quality of institutions is not a strong point of Ukraine as an innovator and is well behind all EU countries.

Next, we turn to the place of Ukraine for indicator of the development of innovations in the ranking of global competitiveness. A large number of different criteria determines the competitiveness of national economies. The Global Competitiveness Index consists of more than 100 indicators that assess the competitiveness of almost all countries. All these variables are combined into 12 benchmarks, which determine the competitiveness of a country.

Thus, the 12th indicator is the country's innovation capacity, which, in turn, consists of a number of subindicators. Consider the dynamics of the most important in our opinion indicators that directly affect the development of innovation in the country.

It is worth noting that in 2018 there were changes in the methodology for calculating the GCI, which was used for the last 12 years. The update of the methodology in 2018, according to the WEF, should help countries better take into account the factors of competitiveness in the fourth industrial revolution. However, because of this it is difficult to conduct a retrospective analysis of the dynamics of various indicators of competitiveness in the period more than one year ago. Therefore, we conducted two analyzes on different indicators in the period from 2014 to 2017 and from 2018-2019.

Considering the sub-indicator of the availability of a qualified workforce in the country, namely engineers and scientists, we can see that here Ukraine has the best results and in 2017 took 25th place, which is the highest result for 5 years. Since 2014, the country has improved its position by 23 steps, ahead of countries such as Portugal, Cyprus, Austria, Italy and Spain. The first place here was taken by the EU country - Finland.

Next, we turn to the analysis of the quality of cooperation between institutions and business in the field of $R$ \& D. Here, Ukraine has one of the worst results, ranking 73rd among 137 countries studied. In addition, the dynamics show that since 2014, Ukraine has risen only one position higher. Thus, in Ukraine there is almost no cooperation between the state, business and research institutions. At the same time, the EU member states: Finland, the Netherlands, Germany, Belgium and Sweden are in the top ten.

Analysis of the sub-indicator of companies' $R \& D$ expenditures showed that in the period from 2014 to 2017, Ukraine only worsened its position. Thus, in 2014, Ukraine ranked 66th, and in 2017 - 76, thus worsening its performance by 10 positions. Ukraine had the best result in 2015, when it took 54th place. The top 10 countries are Switzerland, the United States, Israel, Germany, Japan, Sweden, Finland, the Netherlands, Belgium and Taiwan. That is, half of the top positions belongs to EU member states.

The dynamics of the quality indicator of research institutions indicates that in 2017 Ukraine ranked 60th in the ranking, which is 7 positions higher than in 2014, when Ukraine was in 67th place. Ukraine has overtaken EU countries such as Greece, Croatia and Slovakia and lags behind all other EU member states, including its neighbors Bulgaria (59) and Poland (49). However, compared to 2016, the country lost 10 positions, and compared to 2013 - 17, when it ranked 54th, which is the best result for the period from 2014 to 2017.

Next, we consider the sub-indicators of Ukraine in terms of innovation capacity for 2018-2019, which are calculated according to the new WEF methodology, 
adapted to modern conditions of the fourth industrial revolution.

Thus, in terms of the number of patent applications per 1 million inhabitants in 2019, Ukraine was in 62nd place, or in quantitative terms 1.5-1.6 patents per 1 million of Ukrainians. This is the lowest rate in comparison with the countries of the European Union. The lowest rate among the EU countries belongs to Romania, which is in 49th position, where there are 3.6 patent applications per 1 million inhabitants. In countries such as the United Kingdom, Belgium, Luxembourg, France and the Netherlands, this figure exceeds 100 applications per million inhabitants, and in Denmark, Sweden, Austria, Finland and Germany - 200 applications per million inhabitants.

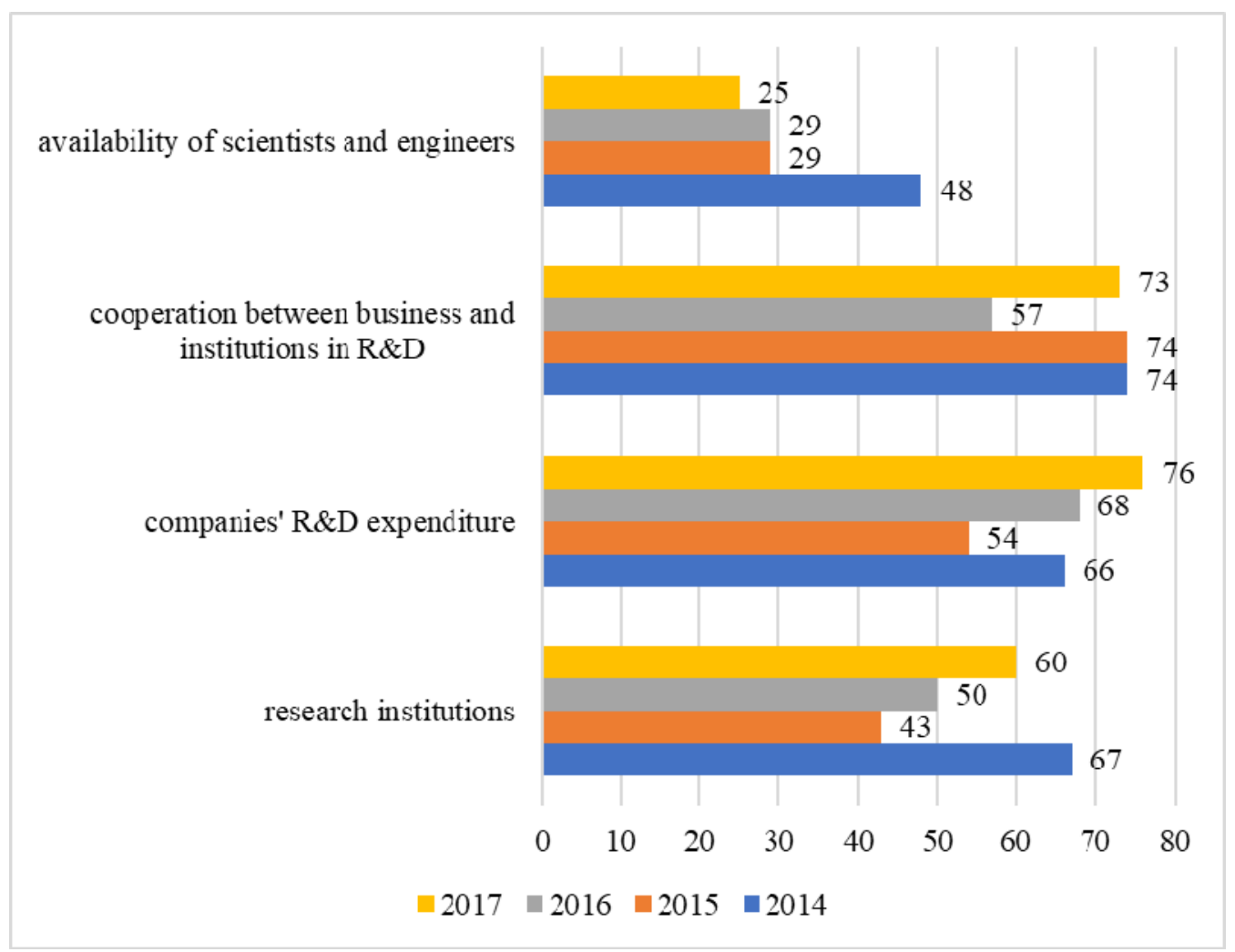

Fig. 2. Dynamics of sub-indicators of the innovation capacity in GCI for Ukraine for 2014-2017 Developed by the authors based on [17]

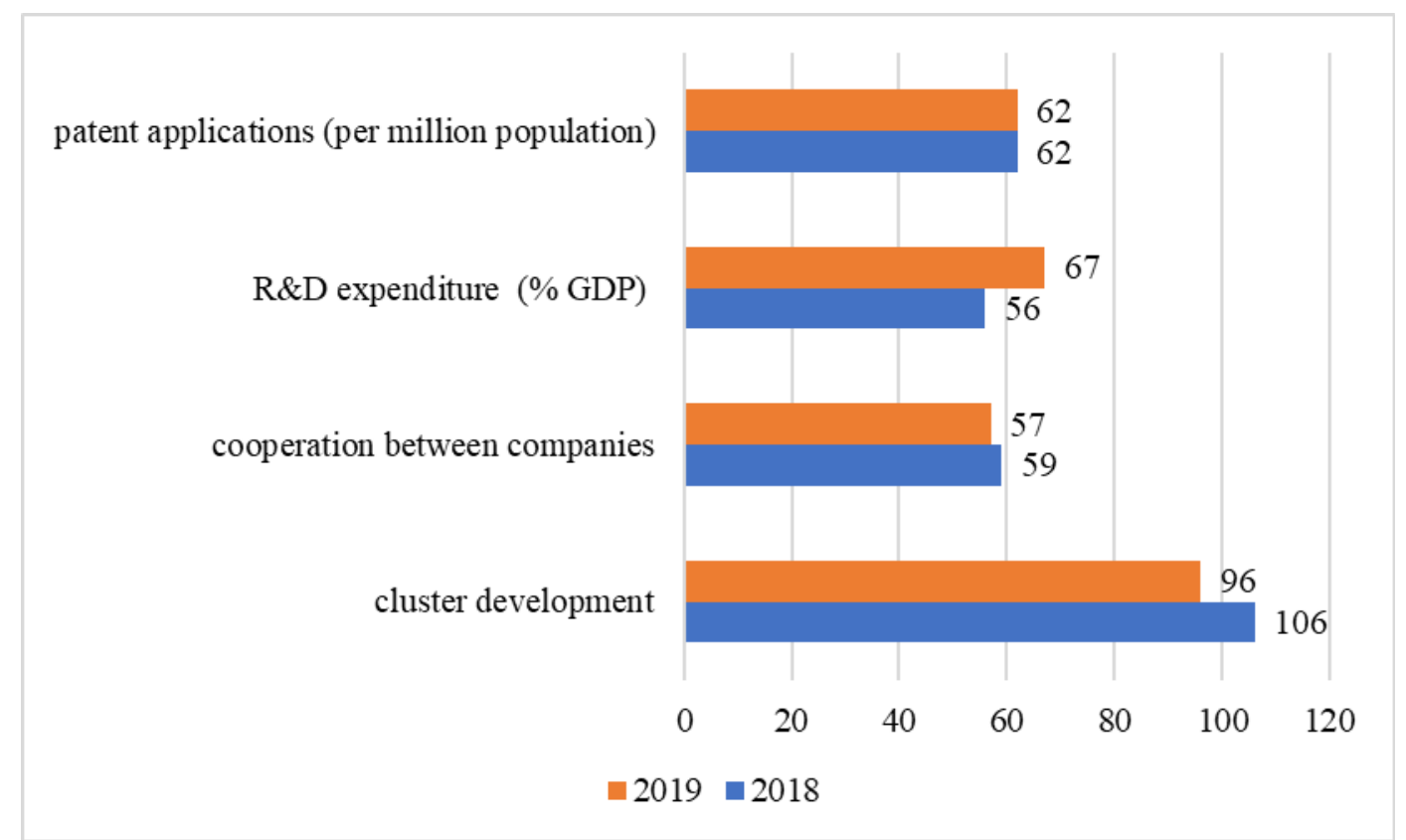

Fig. 3. Dynamics of sub-indicators of the innovation capacity in GCI for Ukraine 2018-2019. Developed by the authors based on [17] 
Regarding the government's expenditure on R\&D in \% of GDP, the country lost 11 positions, so in 2018 Ukraine was in 56th place when R\&D expenditure was $0.6 \%$ of GDP, in 2019 Ukraine from 67 th place spent on $R \& D \quad 0.4 \%$ of GDP. This is the lowest figure among all European Union countries. Among all EU member states, Sweden spends the most on R\&D - 3.4\%, Austria - 3.2\% and Germany - 2.9\%, Denmark - 2.9\% and Finland - 2.8\%. The lowest expenditures among the EU countries are in Malta - 0.5\% and Bulgaria $0.8 \%$ of GDP.

Analyzing the level of cooperation of companies in the field of $R \& D$, we can see that Ukraine has improved the situation by only two positions in a year - 59th place in 2018 against 57th in 2019. Among the EU countries, the closest interaction and cooperation of companies is observed in Germany, the Netherlands, Sweden, Finland and Denmark, which took 3rd, 5th, 6th, 7th and 13th places. The lowest positions are occupied by Hungary, Croatia, Greece, Poland and Cyprus, which belong to the last four decades in the ranking.

Now we turn to the analysis of the sub-indicator of the level of cluster development in countries. In one year, Ukraine was able to improve its position in the ranking by 10 steps at once, but it still remains quite low. In 2018, Ukraine was in 106th place, and in 2019 in 96th. The worst results are only in Lithuania, Romania, Greece and Croatia, which took 97th, 108th, 129th and 132nd places. Among all the studied countries clusters are developed best in Italy (first place), Germany is on the 4th place and the Netherlands is on the 7th place.

Next, we turn to Ukraine's ranking in the European Innovation Scoreboard. The country's innovation efficiency is determined by the consolidated innovation index, which, in turn, consists of more than 25 indicators, which are divided into main groups: framework conditions, investment, innovation and effects.

We selected five key indicators from each group: human resources, the attractiveness of the research system, the level of funding, the valuation of intellectual property, and the export of medium- and high-tech products. The dynamics of the consolidated innovation index in the period from 2014 to 2018 is also given.

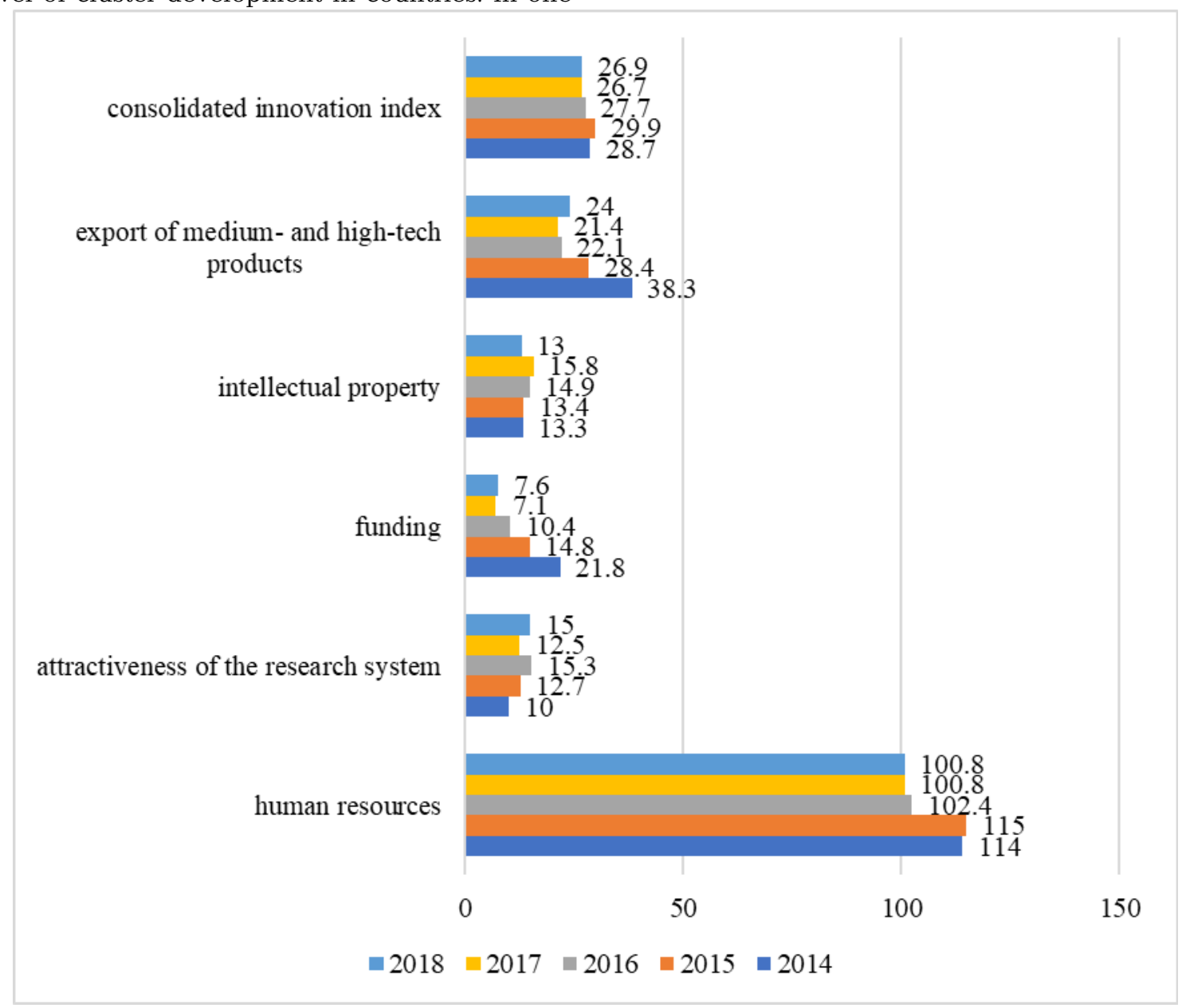

Fig. 4. Dynamics of Ukraine's indicators in the European Innovation Scoreboard 2014-2018 Developed by the authors based on [6]

Thus, analyzing the human resources development indicator, which includes indicators of life expectancy, doctoral graduates and people with higher education, we can see that in 2018 it was
100.8 points, which is on a par with Germany, but less than in 2014, when this figure was 114 points. In general, it is quite a high result. Ukraine is significantly ahead of Bulgaria (64.4 points), 
Romania (16.7 points), Croatia (60.9 points), Hungary (53.6 points), and lags far behind France, Sweden, Finland and the Netherlands, which have 156, 213, 192 and 174 points.

Next, we turn to the analysis of the attractiveness of the research system, which includes indicators of international publications, foreign doctoral students, and citations of scientific publications. Thus, according to this indicator, Ukraine has 15 points, which is five points more than in 2014. Despite progress, Ukraine has very low rates. The country lags slightly behind the countries of Eastern Europe: Bulgaria (23.1 points), Romania (27.2 points), Poland (34.6 points), but has a huge gap with the countries of Western and Northern Europe: France (129 points), UK (177 points), Denmark (207 points), Sweden (189 points).

Regarding the financing of innovations in the country, the dynamics show that since 2014, financial infusions have decreased significantly. In 2018, this indicator received 7.6 points, while in 2014 it had 21.8 points. You can also see that this is the worst result of all the analyzed indicators. Thus, the neighboring countries: Poland, Hungary, Romania and Slovakia in 2018 have 39, 45, 29, and 26 points. Denmark, the Netherlands, Great Britain, France and Germany have more than 100 points.

Considering the dynamics of the intellectual property indicator that characterizes patent activity, we can say that here Ukraine compared to 2014 has not changed its position - 13 points in 2018 against 13.3 points in 2014, but compared to 2017 Ukraine lost three points. Ukraine's results on this indicator are the worst among the EU countries. Romania has also low results - 23 points and Croatia has 29 points. In Eastern Europe (Poland, Hungary, Slovenia, Slovakia, the Czech Republic) this figure exceeds 39 points and in most countries of Western, Southern and Northern Europe (Germany, France, Great Britain, Italy, Denmark, Sweden, Finland) the indicator exceeds 79 points.

The dynamics of exports of medium- and hightech products of Ukraine shows that Ukraine is also gradually losing its position. In 2018, Ukraine had 24 points, and in 2014 - 38, ie lost 14 points. Only Greece has the worse results - 9 points. In the Baltic countries - Lithuania, Latvia and Estonia, this figure is at the level of 50-60 points; In Finland, the Netherlands, Belgium, Great Britain - at the level of 80-100 points; in France, Germany, Ireland, Austria, Finland - more than a hundred points.

Thus, considering the dynamics of the overall consolidated innovation index, it should be noted that the country lost 2 points since 2014 - in 2018 the Index was only 27 points, which is the lowest figure among all EU member states. At the same time, the average index is about one hundred points. Countries with a low Index are Romania with a score of 34 points and Bulgaria with a score of 49 points.

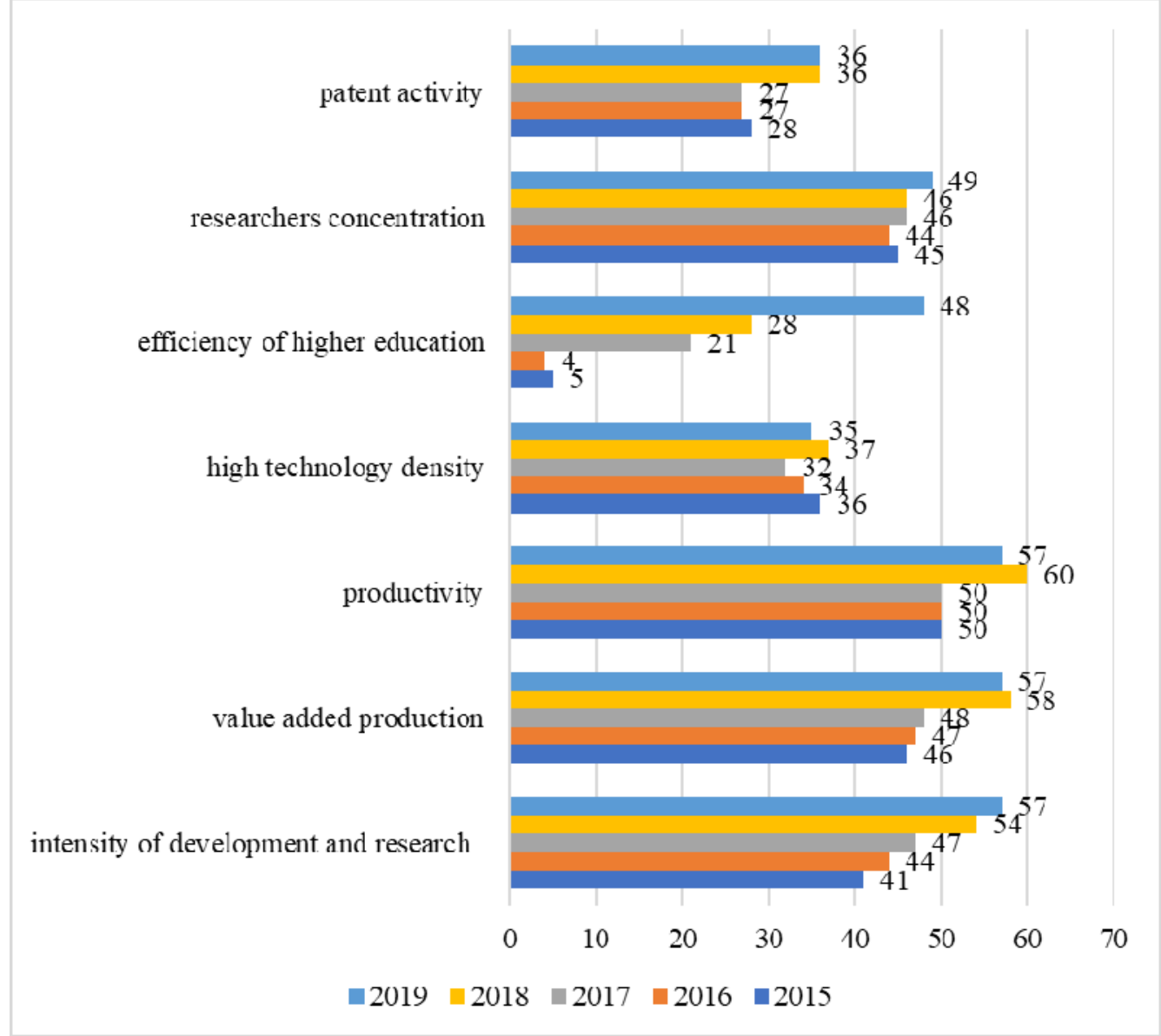

Fig. 5. Dynamics of Ukraine's rating according to the Bloomberg Innovation Index 2015 - 2019 Developed by the authors based on [15] 
Then we go to the analysis of indicators of innovative development of Bloomberg. This index is derived from the evaluation of seven indicators: the intensity of development and research, value added production, productivity, high technology density, efficiency of higher education, researchers concentration and patent activity.

As can be seen from the dynamics of the patent activity indicator, which includes the number of patent applications of residents, the total volume of applications and valid patents per million population; the number of applications for 100 billion dollars of GDP and the share of total patent grants from the world, since 2014, Ukraine has lost eight positions and in 2019 took 36th place. The leader among the EU countries is Germany, which is in the third place.

In terms of the concentration of researchers, which is the number of professionals employed in R\&D per million population, Ukraine has also dropped four places since 2015 and ranks 49th out of 60. In the first place is the EU country - Denmark.

Analyzing the quality of higher education, it should be noted that education, which was the driving force of innovative development, has lost its effectiveness. This indicator includes: the total number of students in the higher education system as $\%$ of the number of school graduates; minimum share of labor force, with higher education; annual number of new graduates of engineering faculties, as \% of the total number of university graduates and \% of those who were employed. Thus, in 2016, Ukraine ranked fourth out of 50 countries, and in 2019 - only 48th. Regression for the last four years amounted to 43 positions. Lithuania ranks second among all countries, which is the best indicator among the EU countries.

In terms of the density of high technologies (the share of registered high-tech public companies from the global level) in 2019, Ukraine ranked 35th, which is one mark better than in 2015. The second place belongs to France and the third one belongs to Germany.

The dynamics of the productivity indicator (the magnitude and three-year change in GDP and GNP per employee at the age of $15+$ ) shows that here Ukraine has the worst results, ranking 57th among 60 countries. Ireland is in first place, Denmark is in sixth place, Finland is in ninth place and Luxembourg is in tenth one.

In terms of value added production (\% of PPP GDP per capita), Ukraine has lost 11 positions in four years, bringing the country to 57 th place out of 60 . This is the worst result for the fife-year period. In first place is Ireland, Germany is in fourth place, and the Czech Republic is in seventh one.

In terms of R\&D intensity (R\&D expenditures, \% of GDP), Ukraine is 57 th out of 60 countries. In four years, the country has lost 16 positions, that indicates a reduction of $R \& D$ funding in the country. Sweden spends on research more than other EU countries ranking fourth out of 60 and followed by Austria and Denmark, which rank sixth and seventh.

Next, we move on to a comparative analysis of the overall place of Ukraine and the EU states in GII, GCI and Bloomberg II in 2019, as well as compare their GDP per capita (thousand US dollars).

Indicators of GDP and the place of Ukraine and EU countries in international rankings 2019

Table 1

\begin{tabular}{|c|c|c|c|c|c|}
\hline & Country & $\begin{array}{c}\text { GDP per capita } \\
\text { (thousand \$) }\end{array}$ & GII & GCI & $\begin{array}{c}\text { Bloomberg } \\
\text { II }\end{array}$ \\
\hline 1 & Austria & 53,50 & 50,90 & 76,60 & 82,4 \\
\hline 2 & Belgium & 49,50 & 50,20 & 76,40 & 79,93 \\
\hline 3 & Bulgaria & 24,60 & 40,30 & 64,90 & 56,59 \\
\hline 4 & Hungary & 34,00 & 44,50 & 65,10 & 68,24 \\
\hline 5 & United Kingdom & 46,60 & 61,30 & 81,20 & 76,03 \\
\hline 6 & Greece & 33,30 & 38,90 & 62,60 & 66,3 \\
\hline 7 & Denmark & 53,80 & 58,40 & 81,20 & 83,22 \\
\hline 8 & Estonia & 35,80 & 50,00 & 70,90 & 62,79 \\
\hline 9 & Ireland & 83,40 & 56,10 & 75,10 & 78,65 \\
\hline 10 & Spain & 41,50 & 47,90 & 75,30 & 65,11 \\
\hline 11 & Italy & 40,40 & 46,30 & 71,50 & 75,76 \\
\hline 12 & Cyprus & 41,40 & 48,30 & 66,40 & 66,3 \\
\hline 13 & Latvia & 31,40 & 43,20 & 67,00 & 62,03 \\
\hline 14 & Lithuania & 36,70 & 41,50 & 68,40 & 61,97 \\
\hline 15 & Malta & 44,40 & 49,00 & 68,50 & 53,48 \\
\hline
\end{tabular}


Вісник ХНУ імені В.Н. Каразіна. Серія “Міжнародні відносини. Економіка. Країнознавство. Туризм”. Вип. 11, 2020

\begin{tabular}{|c|c|c|c|c|c|}
\hline & Country & $\begin{array}{c}\text { GDP per capita } \\
\text { (thousand \$) }\end{array}$ & GII & GCI & $\begin{array}{c}\text { Bloomberg } \\
\text { II }\end{array}$ \\
\hline 16 & The Netherlands & 58,30 & 61,40 & 82,40 & 81,28 \\
\hline 17 & Germany & 53,60 & 58,20 & 81,80 & 88,21 \\
\hline 18 & Poland & 33,90 & 41,30 & 68,90 & 69,98 \\
\hline 19 & Portugal & 33,70 & 44,60 & 70,40 & 65,08 \\
\hline 20 & Romania & 28,00 & 36,80 & 64,40 & 65,15 \\
\hline 21 & Slovakia & 36,60 & 42,00 & 66,80 & 59,36 \\
\hline 22 & Slovenia & 38,40 & 45,30 & 70,20 & 73,93 \\
\hline 23 & Finland & 48,00 & 59,80 & 80,20 & 84 \\
\hline 24 & France & 47,20 & 54,20 & 78,80 & 82,75 \\
\hline 25 & Czech Republic & 38,80 & 49,40 & 70,90 & 70 \\
\hline 26 & Croatia & 27,70 & 37,80 & 61,90 & 55 \\
\hline 27 & Sweden & 54,60 & 63,70 & 81,20 & 85,5 \\
\hline 28 & Ukraine & 9,80 & 37,40 & 57,00 & 48,24 \\
\hline
\end{tabular}

Developed by the authors based on [7, 12-14]

Analyzing the indicators in Table 1, we can say that Ukraine ranks last in almost all indicators compared to EU countries. Thus, the GDP of Ukraine is only 9.8 thousand dollars, which is more than 2 times less than in Bulgaria which the lowest result among EU countries. In the GII rankings, Ukraine is ahead of only Romania, and in the GCI and Bloomberg II rankings Ukraine ranks last.
To determine the impact of innovation in the country on the state of its economic development, we conducted a correlation analysis, where GDP - Y, GII X1, GCI - X2, Bloomberg II - X3.

The correlation analysis was performed according to the following formula [12]:

$$
\mathrm{r}=\frac{\sum_{i=1}^{n}\left(x_{i}-\bar{X}\right) \times\left(\sum_{i}-\bar{Y}\right)}{\sqrt{\sum_{i=1}^{n}\left(x_{i}-\bar{X}\right)^{2}} \times \sum_{i=1}^{n}\left(\bar{x}_{i}-\bar{Y}\right)^{2}}
$$

Where $X_{i}, \quad Y_{i}$ are the numerical values of the quantities between which the correlation is established, $\bar{X}, \bar{Y}$ are their arithmetic mean values. For independent values $r=0$, for functional dependences $\mathrm{r}= \pm 1$. We obtained the following results which are presented in table 2 .

The results of cluster analysis

\begin{tabular}{|c|c|c|c|}
\hline & GII (X1) & GCI (X2) & Bloomberg II (X3) \\
\hline GDP per capita (Y) & 0,7861 & 0,7768 & 0,7513 \\
\hline
\end{tabular}

Developed by the authors

As can be seen from the table, each correlation coefficient, which shows the dependence of $\mathrm{Y}$ on $\mathrm{X} 1$, $\mathrm{X} 2$ and $\mathrm{X} 3$ is greater than 0.75 , which indicates a very strong dependence of the level of economic development on the level of innovation development in the country.

After analyzing the state of innovation development of Ukraine, it is reasonable to consider in detail what factors prevent Ukraine from implementation of its innovation potential and what advantages the country has that can positively affect its innovation development. To do this, we conducted a SWOT-analysis, the matrix of which is presented in table 3.
From the SWOT matrix you can see that Ukraine has many unrealized opportunities in the field of innovation development. In order to realize the existing opportunities and avoid potential threats, it is reasonable to consider the experience of EU member states in realizing their innovation potential, which may be applied to Ukraine.

First of all, the creation, development, implementation and support of innovation capacity in the EU is achieved through the stimulation of innovation in the framework of strategic programs at various levels. The first such program was the Lisbon Strategy, launched in 2000 by EU Heads of States and Governments. 
The goal of the Lisbon Strategy was to make Europe the most competitive and dynamic growing knowledge-based economy and capable of sustainable development.

After the implementation of the Lisbon Strategy, the European Union adopted a new program in 2010, called Europe 2020, which is an updated large-scale EU development strategy until 2020. And in 2014 the Horizon 2020 framework program was created to implement the Europe 2020 strategy.

SWOT analysis matrix

Table 3

\begin{tabular}{|c|c|}
\hline Strengths & Weaknesses \\
\hline $\begin{array}{l}\text { 1. Employment in science-intensive industries } \\
\text { 2. Population with complete secondary and higher } \\
\text { education } \\
\text { 3. Number of graduates in science and technology } \\
\text { 4. Expenditures on education } \\
\text { 5. Creative potential } \\
\text { 6. Ease of obtaining a loan }\end{array}$ & $\begin{array}{l}\text { 1. Lack of a mechanism for protecting foreign } \\
\text { investors } \\
\text { 2. Low development of clusters } \\
\text { 3. Low quality of research institutions } \\
\text { 4. R\&D expenditures } \\
\text { 5. Low share of exports of creative and high-tech } \\
\text { products } \\
\text { 6. Use and access to ICT } \\
\text { 7. The share of medium and small business with } \\
\text { innovative products }\end{array}$ \\
\hline Opportunities & Threats \\
\hline $\begin{array}{l}\text { 1. Implementation the third and fourth generation } \\
\text { mobile technologies } \\
\text { 2. Creation regulatory framework to protect } \\
\text { investors } \\
\text { 3. Development of modern national and } \\
\text { international clusters } \\
\text { 4. Involvement of qualified specialists in the } \\
\text { creation of innovative technologies } \\
5 \text {. Preferential lending for innovative strata } 6 . \\
\text { Providing educational institutions with modern } \\
\text { material and technical equipment }\end{array}$ & $\begin{array}{l}\text { 1. Brain drain due to non-realization of abilities in } \\
\text { Ukraine } \\
\text { 2. Increasing the gap with the EU in the field of } \\
\text { innovation } \\
\text { 3. Lack of up-to-date information on technological } \\
\text { progress in the world due to low use of ICT } \\
4 \text {. Consolidation of the status of a raw materials } \\
\text { supplier country } \\
\text { 5. Impossibility to occupy a niche in the world market } \\
\text { of innovative goods } \\
\text { 6. Loss of confidence of foreign investors }\end{array}$ \\
\hline
\end{tabular}

Developed by the authors

Ukrainian organizations also joined Horizon 2020 in 2014. So far (as of January 2019), Ukrainian participants have received 171 grants totaling 30 million euros. Overall, domestic institutions and enterprises have participated 238 times since 2014 [8].

Thus, mainly innovative ideas and projects in Ukraine originate in research organizations universities, research institutes and independent laboratories, because the largest number of patents belong to them. However, despite their relatively large number, the number of inventions is much smaller due to the fact that the implementation of innovative ideas and projects requires the participation of many other structures, which involve qualified engineers, managers and representatives of a number of other professions. The most effective form of cooperation in this case are regular live contacts of the main participants in the innovation process. This is the form of cooperation inherent in clusters.

Today the policy of EU countries is aimed at helping clusters through the development of innovation infrastructure, strengthening networking and training, investment, spreading knowledge among the participants of clusters, which leads to increased productivity of firms. Using the benefits of European integration potential now allows clusters of different countries in Europe to consolidate, thus creating an association of international clusters. This allows them to move from sharing experiences to practical cooperation.

Thus, the EU experience can form the basis for the formation of national cluster regulation mechanisms in Ukraine, the development of national strategic development programs and cooperation in the European Economic Area, for example, through the creation of national and international clusters and active participation in future EU framework programs.

Conclusions. Examining the state of development of Ukraine's innovations on the basis of international rankings, it was found that according to the Global Innovation Index, the Global Competitiveness Index, the Bloomberg Innovation Rating and the European Innovation Scoreboard, six years after signing the association agreement, Ukraine has improved its creative potential, succeeded in the development of the business environment, and educational potential is consistently at the level of most European countries. However, the country has a low level of development of institutes, research institutions, 
clusters and infrastructure. There are no mechanisms to protect copyright, intellectual property or investors.

In order to solve the existing problems in the field of innovation development in the country, the main tasks of the state innovation policy of Ukraine should be the creation of effective institutions of government, a transparent tax system and mechanisms to protect foreign investors, copyright and intellectual property, increase funding for research and development, the establishment of technology transfer centers on the basis of universities and the full use of the benefits and opportunities of the Association Agreement with the EU.

\section{ІННОВАЦІЙНИЙ РОЗВИТОК УКРАЇНИ В КОНТЕКСТІ РЕАЛІЗАЦІї УГОДИ ПРО АСОЦІАЦІЮ}

Матюшенко Ігор Юрійович, доктор економічних наук, професор, Харківський національний університет імені В.Н. Каразіна, пл. Свободи, 4, Харків, Україна, 61022, e-mail: imatyushenko@karazin.ua, ORCID: https://orcid.org/0000000198669025

Редько Наталія Сергіївна, студент, Харківський національний університет імені В.Н. Каразіна, пл. Свободи, 4, Харків, Україна, 61022, e-mail: natalia.redko98@gmail.com, ORCID: https://orcid.org/0000-0002-1085-5673

Підписання у 2014 році Угоди про асоціацію передбачає розвиток інноваційного співробітництва між Україною та країнами $\epsilon C$, тож доцільно провести аналіз розвитку інновацій в Україні з моменту підписання Угоди задля оцінки дієвості даного договору та виявлення слабких та сильних сторін України як країни-новатора, а також надання відповідних рекомендацій Об'єктом дослідження статті $€$ інноваційний розвиток країни, відповідно, предметом є сучасний стан інноваційного розвитку України в умовах реалізації Угоди про асоціацію з Європейським Союзом. Метою дослідження статті $є$ визначення рівня розвитку інновацій в України, виділення основних переваг та недоліків та надання відповідних рекомендацій для поліпшення умов інноваційного розвитку в країні в рамках реалізації Угоди про Асоціацію.

Задля досягнення мети дослідження було проведено аналіз динаміки показників, що характеризують рівень розвитку інновацій в країні з моменту підписання Угоди. Базою даних є міжнародні рейтинги, такі як Глобальний індекс інновацій, Індекс інноваційного розвитку Bloomberg, Глобальний індекс конкурентоспроможності і Табло інноваційного розвитку ЕС.

Отримано такі результати: на основі проведеного аналізу динаміки досліджуваних показників рівня розвитку інновацій в Україні виявлено слабкі сторони, що заважають Україні реалізувати свій інноваційний потенціал, та розраховано коефіцієнт кореляції для встановлення взаємозв'язку між розміром ВВП на душу населення та рівнем розвитку інновацій. Висновки: незважаючи на діючу Угоду між Україно та ЄС, що має стимулювати розвиток технологій в Україні, рівень інноваційного розвитку України все ще залишається низьким та значно відстає від рівня країн ЄС. Таким чином Україна використовує переваги від Асоціації з ЄС не у повному обсязі. Розроблені рекомендації, щодо підвищення рівня розвитку інновацій в Україні, засновані на європейському досвіді, повинні допомогти виробити стратегію створення та впровадження інновацій, знайти шляхи підвищення конкурентоспроможності економіки держави шляхом реалізації свого інноваційного потенціалу.

Ключові слова: європейська інтеграція, інноваційний потенціал, показники рівня інноваційного розвитку, Угода про Асоціацію з ЄС.

\section{ИННОВАЦИОННОЕ РАЗВИТИЕ УКРАИНЫ В КОНТЕКСТЕ РЕАЛИЗАЦИИ СОГЛАШЕНИЯ ОБ АССОЦИАЦИИ}

Матюшенко Игорь Юрьевич, доктор экономических наук, профессор, Харьковский национальный университет имени B.H. Каразина, пл. Свободы, 4, Харьков, Украина, 61022, e-mail: imatyushenko@karazin.ua, ORCID: https://orcid.org/0000000198669025

Редько Наталия Сергеевна, студент, Харьковский национальный университет имени В.Н. Каразина, пл. Свободы, 4, Харьков, Украина, 61022, e-mail: natalia.redko98@gmail.com, ORCID: https://orcid.org/0000-0002-1085-5673

Подписание в 2014 году Соглашения об ассоциации предусматривает развитие инновационного сотрудничества между Украиной и странами ЕС, поэтому целесообразно провести нализ развития инноваций в Украине с момента подписания Соглашения для оценки эффективности данного Соглашения и выявления слабых и сильных сторон Украины как страныноватора и предоставления соответствующих рекомендаций. Объектом исследования статьи является инновационное развитие страны, соответственно, предметом является современное состояние инновационного развития Украины в условиях реализации Соглашения об ассоциации с Европейским Союзом. Целью исследования статьи является определение уровня развития инноваций в Украине, выделение основных преимуществ и недостатков, а также предоставление соответствующих рекомендаций по улучшению условий инновационного развития в стране в рамках реализации Соглашения об Ассоциации.

Для достижения цели исследования был проведен анализ динамики показателей, характеризующих уровень развития инноваций в стране, с момента подписания Соглашения. Базой данных является международные рейтинги, такие как Глобальный индекс инноваций, Индекс инновационного развития Bloomberg, Глобальный индекс конкурентоспособности и Табло инновационного развития ЕС.

Получены следующие результаты: на основе проведенного анализа динамики исследуемых показателей уровня развития инноваций в Украине выявлены слабые стороны, которые мешают Украине реализовать свой инновационный потенциал. Также рассчитан коэффициент корреляции для установления взаимосвязи между размером ВВП на душу населения и уровнем развития инноваций. Выводы: несмотря на действующее Соглашение между Украиной и ЕС, что должно стимулировать развитие технологий в Украине, уровень инновационного развития Украины все еще остается низким и значительно отстает от уровня стран ЕС. Таким образом, Украина использует преимущества от Ассоциации с ЕС не в полном объеме. Разработанные рекомендации по повышению уровня развития инноваций в Украине, основанные на европейском опыте, должны помочь выработать стратегию создания и внедрения инноваций, найти пути повышения конкурентоспособности экономики государства путем реализации своего инновационного потенциала.

Ключевые слова: европейская интеграция, инновационный потенциал, показатели уровня инновационного развития, Соглашение об Ассоциации с ЕС.

\section{References}

1. A. Kniazevych, V. Kyrylenko, L. Golovkova. (2019). Innovation infrastructure of Ukraine: assessment of the effectiveness of the action and ways of improvement. Available at: 
https://www.researchgate.net/publication/325648797_INNOVATION_INFRASTRUCTURE_OF_UKRAINE_ASSE SSMENT OF THE_EFFECTIVENESS OF THE_ACTION_AND WAYS_OF_IMPROVEMENT

2. A. Rusnak, S. Prokhorchuk. (2018). Innovative capacity of Ukraine's economy in the international context. Available https://www.researchgate.net/publication/328287094_INNOVATIVE_CAPACITY_OF_UKRAINE'S_ECONOMY_ IN_THE_INTERNATIONAL_CONTEXT

3. Association Agreement between the European Union and Ukraine (2014). Available at: https://www.kmu.gov.ua/en/yevropejska-integraciya/ugoda-pro-asociacyu

4. Babenko, V., Pasmor, M., Pankova, Ju., Sidorov, M. (2017). The place and perspectives of Ukraine in international integration space. Problems and Perspectives in Management, Vol. 15, Issue 1, pp. 80-92. doi: http://dx.doi.org/10.21511/ppm.15(1).2017.08

5. Babenko, V., Perevozova, I., Kravchenko, M., Krutko, M., and Babenko, D. (2020). Modern processes of regional economic integration of Ukraine in the context of sustainable development. E3S Web Conf., 166 (2020) 12001. doi: https://doi.org/10.1051/e3sconf/202016612001

6. European innovation scoreboard. (n.d.). (2014-2019). European innovation scoreboard. Available at: https://ec.europa.eu/growth/industry/policy/innovation/scoreboards_en

7. GDP per capita (current US\$) (n.d.). (2019). Available at: https://data.worldbank.org/indicator/NY.GDP.PCAP.CD

8. Gorizont 2020. (n.d.). (2019). [Horizon 2020]. MON of Ukraine. Available at https://mon.gov.ua/ua/tag/gorizont-2020. (in Ukrainian).

9. I. Yegorov, I. Odotiuk, O. Salihova (Eds.) (2015). Implementatsiya vysokykh tekhnolohiy v ekonomiku Ukrayiny [Implementation of high technologies in the economy of Ukraine]. NAS of Ukraine. (in Ukrainian).

10. I. Yu. Matiushenko. (2016). The Methodical Approach to Evaluating the Innovation Potential of Ukraine as a Prerequisite for Implementing the Fourth Industrial Revolution and the Association with the EU. Business inform, №11, $70-76$.

11. I. Yu. Matyushenko, N. Redko. (2019). The assessment of Ukraine's readiness for innovations in the conditions of the spread of technologies of the new industrial revolution. Acta Innovations, № 33, 5-19.

12. Korelyatsiya. Koefitsiyent korelyatsiyi. (n.d.). [Correlation. Correlation coefficient]. Available at: https://teta.at.ua/statustuka/lekcija13.pdf (in Ukrainian).

13. M. Kyzym. (2011). Promyslova polityka ta klasteryzatsiya ekonomiky Ukrayiny. [Industrial policy and clustering of Ukrainian economy] PH INZHEK. (in Ukrainian).

14. Ramazanov, S., Antoshkina, L., Babenko, V., \& Akhmedov, R. (2019). Integrated model of stochastic dynamics for control of a socio-ecological-oriented innovation economy. Periodicals of Engineering and Natural Sciences, vol. 7 , no. 2, pp. 763-773. doi: http://dx.doi.org/10.21533/pen.v7i2.557

15. The Bloomberg Innovation Index. (n.d.). (2015-2019). The Bloomberg Innovation Index. Available at: https://www.bloomberg.com/

16. The Global Competitiveness Report. (n.d.). (2014-2019). The Global Competitiveness Report. Available at: https://www.weforum.org/

17. The Global Innovation Index. (n.d.). (2014-2019). The Global Innovation Index. Available at: https://www.globalinnovationindex.org/analysis-indicator.

18. V. Khaustova. (2015). Promyslova polityka v Ukrayini: formuvannya ta prohnozuvannya [Industrial Policy in Ukraine: Formation and Forecasting]. PH INZHEK. (in Ukrainian).

19. Ye.I. Maslennikov, M.I. Dimitrieva. (2016). Analytical providing of monitoring innovative development of industry the southern region. Available at: https://cyberleninka.ru/article/n/analytical-providing-of-monitoringinnovative-development-of-industry-the-southern-region/viewer

\section{Лiтepaтура}

1. Kniazevych A., Kyrylenko V., Golovkova L. Innovation infrastructure of Ukraine: assessment of the effectiveness of the action and ways of https://www.researchgate.net/publication/325648797_INNOVATION_INFRASTRUCTURE_OF_UKRAINE_ASSE SSMENT_OF_THE_EFFECTIVENESS_OF_THE_ACTION_AND_WAYS_OF_IMPROVEMENT

2. Rusnak A., Prokhorchuk S. Innovative capacity of Ukraine's economy in the international context. URL: https://www.researchgate.net/publication/328287094_INNOVATIVE_CAPACITY_OF_UKRAINE'S_ECONOMY_ IN_THE_INTERNATIONAL_CONTEXT

3. Association Agreement between the European Union and Ukraine. URL: https://www.kmu.gov.ua/en/yevropejska-integraciya/ugoda-pro-asociacyu

4. Babenko, V., Pasmor, M., Pankova, Ju., Sidorov, M. The place and perspectives of Ukraine in international integration space. Problems and Perspectives in Management. 2017. Vol. 15, Issue 1. P. 80-92. doi: http://dx.doi.org/10.21511/ppm.15(1).2017.08

5. Babenko V., Perevozova I., Kravchenko M., Krutko M., Babenko D. Modern processes of regional economic integration of Ukraine in the context of sustainable development. E3S Web Conf. 2020. 166 (2020) 12001. doi: https://doi.org/10.1051/e3sconf/202016612001

6. European innovation scoreboard. URL: https://ec.europa.eu/growth/industry/policy/innovation/scoreboards_en

7. GDP per capita (current US\$). URL: https://data.worldbank.org/indicator/NY.GDP.PCAP.CD

8. Горизонт 2020 / MOH України. URL: https://mon.gov.ua/ua/tag/gorizont-2020. 
9. Імплементація високих технологій в економіку України : наукова доповідь / за ред. А-ра екон. наук, проф. І.Ю. Сгорова, А-ра екон. наук І.В. Одотюка, А-ра екон. наук О.Б. Саліхової ; НАН України, АУ «Інститут екон. та прогнозув. НАН України». К., 2016. 166 с.

10. Matiushenko I. Yu. The Methodical Approach to Evaluating the Innovation Potential of Ukraine as a Prerequisite for Implementing the Fourth Industrial Revolution and the Association with the EU. Business inform. 2016. № 11. C. $70-76$.

11. Matyushenko I. Yu., Redko N. The assessment of Ukraine's readiness for innovations in the conditions of the spread of technologies of the new industrial revolution. Acta Innovations 2019. № 33. C. 5-19.

12. Кореляція. Коефіцієнт кореляції. URL: https://teta.at.ua/statustuka/lekcija13.pdf

13. Кизим М.О. Промислова політика та кластеризація економіки України: монографія. Х.: ВА «Інжек», 2011. $304 \mathrm{c}$.

14. Ramazanov S., Antoshkina L., Babenko V., Akhmedov R. Integrated model of stochastic dynamics for control of a socio-ecological-oriented innovation economy. Periodicals of Engineering and Natural Sciences. 2019. vol. 7, no. 2. P. 763-773. doi: http://dx.doi.org/10.21533/pen.v7i2.557

15. The Bloomberg Innovation Index. URL: https://www.bloomberg.com/

16. The Global Competitiveness Report. URL: https://www.weforum.org/

17. The Global Innovation Index. URL: https://www.globalinnovationindex.org/analysis-indicator.

18. Хаустова В. Промислова політика в Україні: формування та прогнозування: монографія. Х.: ВА «Інжек», 2015. $384 \mathrm{c}$.

19. Maslennikov Ye.I., Dimitrieva M.I. Analytical providing of monitoring innovative development of industry the Southern region. Economics: time realities. 2016. № 2 (24). URL: https://cyberleninka.ru/article/n/analyticalproviding-of-monitoring-innovative-development-of-industry-the-southern-region/viewer 